\title{
A Comparative Study on the Legal Education Model in Saudi Arabia
}

\author{
Awad Ali Alanzi ${ }^{1}$ \\ ${ }^{1}$ Assistant Professor, Department of law, College of Business Administration, Prince Sattam bin Abdulaziz \\ University, Saudi Arabia. \\ Correspondence: Awad Ali Alanzi, Assistant Professor, Department of law, College of Business Administration, \\ Prince Sattam bin Abdulaziz University, 173 Alkharj 11942, Saudi Arabia.
}

Received: December 11, 2019

Accepted: December 28, 2019

Online Published: January 7, 2020

doi:10.5430/ijhe.v9n2p70

URL: https://doi.org/10.5430/ijhe.v9n2p70

\begin{abstract}
This research mootivates to identify the legal eduaction model in the Arab region and Saudi Arabia in particular. It is found that Arab legal system is derived from the Roman law and French models. The French teaching model is spread in the Kingdom through the professors educated from the French law schools. The french model of legal education follows the lecture approach. The formal legal education in the Kingdom is initiated by Institute of Public Administration (IPA) during 1970s. IPA offered two-years disploma after Sha'ria graduation. Afterwards, King Saud University started the systemetic legal education since 1980s. Law graduatea are required atleast 4-years law degree and 3-years apprenticeship in a law firm as a trainee lawyer.This research also differentiates the legal education system of France, Saudi Arabia and US. We find that that Saudi Arabian system is more similar to French system and lesser similar to the US system.
\end{abstract}

Keywords: legal eduaction model, French model, lecture approach

\section{Introduction}

In the early years of the Kingdom of Saudi Arabia, the French legal education model was initially used to train legal practitioners and affected Arab law schools in numerous ways. To fully understand French impact on Saudi Arabian legal instruction techniques, it is essential to acknowledge that Saudis have a distinctively different legal system as compared to western culture; this is especially so in the Arabian Peninsula (Sultany, 2018). Given the location and import of Saudi Arabia, it was less affected by the fusion of the western legal values. A mixture of Arabian law by western culture led to the introduction of French teaching methods, especially in Egypt, a country whose culture appears to be mingled between the East and the West. French legal education methods include the lecture/textbook and legal theory study methods. These methods were introduced into the Arabic the legal instruction systems where instruction was often conducted through lectures. Furthermore, the Arab systems employed lecture-based legal education to train the students before allowing them to work under already established legal professionals. Since that time, the case study and problem-focused approaches have gained popularity in most higher learning institutions, but not in legal education within the Saudi law institutions. Before the $19^{\text {th }}$ century, the entire western legal framework was external to the Arabs (Sultany, 2018). However, the introduction of western influence has undermined many of the traditions of the Islamic communities causing unintended conflict.

Historically, the Arab territories have been favorable to the influence of legal systems emanating from Roman law. However, French interest in the region dated back to the Ottoman rule and was extended, after France, under the leadership of Napoleon, carved out her colonial empire in North Africa, occupied Egypt, and created French mandates in Syria and Lebanon (Hanson, 1987). To protect French interests, administrative and legal institutions were fashioned adapting themselves to local conditions until today the administrative systems of the Islamic states in the Middle East find themselves strongly marked by the French system. In the legal sphere, this influence was felt in the formation of domestic legal institutions copied from the French. The French codified system of law was easily adapted and rapidly spread throughout the Middle East. The majority of Arab laws were inspired by the French system and consisted of the work of experts and professors who hold their law degrees from French schools, in particular, Egyptian, Lebanese, and Syrian scholars (Hanson, 1987).

While the French legal system distinguishes between public and private law, the Arab law schools automatically have applied this classification in their law schools' curricula. This simulation in the culture of legal education has entrenched the notion of subsidiarity to the French model regarding the legal system and legal education system as well. 
Now, various higher education institutions in Arabic countries such as Egypt have embraced numerous western aspects of their teaching methods. Modernization has played a role in this transition and fusion, because at current technological levels, interdependency has increased, and it has become close to impossible for the Islamic countries to isolate themselves, culturally or otherwise.

The present study is aimed at exploring the present legal education model of Saudi Arabia and its evolution from historical perspective. It also sheds lights on the major differences in the Saudi legal educational model in comparison of the models of French and US. In the historical perspective, Egyptian graduates from French schools mostly employed for teaching legal education and spread the lecture model of teaching in the Arab world in the nineteen century. Saudi Arab is also followed the same approach in the legal education. Moreover, Institute of Public Administration has initiated the formal legal education for the Sharia graduates during 1970s and King Saud University started the graduation program for the formal legal education during 1980s. In the evaluation period of Saudi legal education, French model was remained dominant throughout the history.

\section{Saudi Legal Education}

Saudi Arabian legal education found its roots in a government institution known as "the Institute of Public Administration" (IPA). The establishing of the IPA and its subsequent actions were a tremendous leap into the $21^{\text {st }}$ Century. It was created in response to government officials and respected academics who recognized the coming of a modern era and its urgent public need to establish a legal legal training in the country. It began participating in the development of a new legal system for the country evolving out of the officials' decisions. Accordingly, they determined to introduce the first graduate diploma program for teaching legal sciences in the Kingdom. The IPA was launched to educate and increase the proficiency of governmental employees within the Kingdom, and it had been carrying the banner of the entry of legal education into the country despite the displeasure of some community groups protesting the start of the program form in one form or another.

Undeniably, the IPA's mission has been the elevation of the role of public officials to significantly support administration efforts to improve national economic development. Nonetheless, it is not an institution of higher education for awarding academic degrees in various academic disciplines. The task of the legal program at IPA has been to train Saudis in adjudicating disputes as members of administrative committees with legal jurisdiction and providing specialists in legal advice. Thus, the modern form of the legal education system was introduced into the Saudi educational field through IPA in the early part of the1970s. The Department of Law at IPA was the Saudi institute that held the first academic programs of law studies in the country. The IPA could not be considered as an official university (Al-Jarbou, 2007). The IPA offers to provide both academic and non-academic services to other agencies and the public as a whole. Despite this as a national institute, the IPA provides a post-graduate diploma program in legal sciences to graduate students. The legal program has been focusing on modern legal theories and the legislation and regulations enacted by the government rather than on the legal system. However, the enrolment in the law diploma program at the IPA is to those limited to those who hold a bachelor's degree in Sharia from any Sharia college or department or Judiciary Department in the country. The law diploma degree at the IPA is a 2-year full-time program for preparing candidates to work in the legal field in the Kingdom.

It was in the early 1980s that at first, Saudi students at King Saud University (KSU) in Riyadh began to take formal law classes with related course materials and formal curriculum. Once the university began to offer the science and theory of law classes, accompanied by analytical skills of Law, it began to fill the vacuum of legal education that had existed in the country. Finally, academic-led education was beginning to supersede personal training and practitioner-led training. The modern curriculum is designed to train law students in the tenets and virtues of viable historical law as well as instructing them in modern law. For years though, the Saudi legal education had been frozen in time. There were several reasons for this state including cultural, religious, and educational planning factors. The significant issue facing legal education in the country was the acceptance of a new application of the law and getting it approved for instruction. The acceptance procedure was too complicated because the law in the perspective of the majority of Saudis is considered human-produced. The people are required to follow divine law. This fallacy was caused by the belief of former religious scholars that human-made law might oppose Sharia, which is not a law but is a covenant with the divine. While the Law, as understood by academics, is a humanistic science of framing and collecting provisions, principles, and rules in codes by the authoritative source of a country. If legislators wish to consider Sharia as the primary source of legislation, this will refute the issue of conflict which is the case in the Kingdom of Saudi Arabia.

Also, the adoption of the Egyptian-French approach to legal education since the establishment of the legal education system, and the subsequent tendency was to send off missions of faculty members of law schools to France to pursue 
higher education contributed to the consolidation of the prevailing pattern of education in the country. In the perspective of the old generation of officials of legal education and law educators who arose under this type of teaching methodology, the concept of renewal of the education method may lead to undermining the confidence gained by that generation. The revolution of legal education in the country since 2006 and beyond is focused on quantity of increasing law schools and improving legal curriculum in a modest way rather than focusing on substance, and without regard to the development of methods and curricula of education and upgrading its outputs.

It is understood that legal education is another facet of a national legal system. Since the French legal system has a direct influence on the Saudi legal system, it has a legal education with a similar impact. Distinctively, Saudi Arabia is a country that was never under the influence of any European or foreign occupation but has been influenced by French jurisprudence. This is because that French legal concepts were well-known throughout the Arab World long even before the formulation and unification of the Kingdom of Saudi Arabia. It is Egypt that has been the conduit for the reception of French legal principles and culture of legal education into the Arab World including Saudi Arabia. The Kingdom has now entered the $21^{\text {st }}$ century along with a path of development integrating western legal concepts for the benefit of its citizens while retaining its Islamic heritage (Hanson, 1987).

It is essential to bear in mind from the outset that when the legal programs were initially established in the Kingdom, the educational authorities avoided using term "Law" (kanun in Arabic) when referring to the legal education programs. The reasoning behind this is that Saudis believe only God can legislate law, therefore, the word "kanun" is not used. However, in place of kanun which represents the secular or temporal law, Saudi Arabia employs the word 'nizam' meaning "regulation." Therefore, legal degrees and law departments are given degrees with "'an'zmah" names instead of "kanun" for the law programs. However, this practice is gradually being phased out with some law schools using term "kanun" in their title.

\section{Saudi Law Instructional Method}

Generally speaking, teaching methodologies can be considered a way of learning by providing students with comprehensive knowledge in specific disciplines, subjects, and topics of literature and sciences. In other words, teaching methods are described by a professor as strategies which he or she uses for the delivery of lessons to attain specific goals and objectives in the class. In the Kingdom, the teaching of humanity sciences including law studies is based on traditional teaching techniques comprised of non-interactive lectures. The lecture method is considered a cornerstone of colleges and universities in the country, and an effective manner used to teach organized bodies of knowledge, theories, ideas, and facts to students. Typically, researchers have proven that the lecture method is considered a popular teaching model in different subjects and it is the traditional style of teaching still found in many schools and colleges around the world (Kaur, 2011).

Since the establishment of the legal education system in the official universities during the 1980s in the Kingdom of Saudi Arabia, law programs have employed the Egyptian legal education method which becomes the prevalent model in law schools or departments until the present-day in the country. The circumstances of a shortage to prepare graduates to be principled advocates for justice and the rule of law in the country at that time contributed to adopting this kind of educational methodology in the law schools. The goal of legal education was to provide the country with qualified candidates to serve in the legal employment and replace Saudis in jobs occupied by non-Saudis. The legal profession was not widely accepted and was no law enacted regulating it for reasons that already explained in this study. Thus, the programs designed with a single perspective priority without consideration of developing the skills of lawyers thinking or abilities of how to argue. However, the tremendous increase in legislative and regulatory activity from law-makers signaled the need to better prepare law students for a practice that increasingly involves enacted law (Romantz, 2003).

The consequence is that in the move towards better academic preparation, Saudi universities have had traditionally pursued the education perspective of an abstract approach to knowledge. This approach views texts and codes as a system of norms which are interpreted through highly formal and rational means (Flood, 2011). Otherwise, modern legal education through using elements of craft training and methodology content developed is characterized by providing the student with life experience rather than knowledge from books. In the Kingdom, it is time to focus on the results of legal education to gain the confidence of legal professionals and those interested in profession-related sectors. The method of education needs to be reviewed and scrutinized and benefit from the experiences of developed countries in this regard. The education system should be more useful in training students to be lawyers, jurists, and counselor who will be able to sit on international legal bodies after graduation.

A theoretical method in legal education has produced a deep gulf between the preparation of law students in the law institutions and the law practice in the Kingdom. The highlighted issue is the method of teaching and legal education 
purposes. Attention must be attracted to the inappropriateness of legal education programs provided in the Kingdom to the stage of scientific and cognitive revolution, given the advanced position occupied by the State between the two countries. Saudi Arabian authorities are attempting to harmonize legal instruction with economic and social development to be capable of meeting the needs of modern society. Thus, the tremendous increase in legislative and regulatory activity from lawmakers signaled the need to better prepare law students for a practice that increasingly involved the enacted law (Romantz, 2003). Supposedly, in practice, the law school graduates are educated to be qualified for all legal works in both public or private sector and eligible for judiciary tasks, not to be unqualified for law practice. However, in quality education, the hardest perspective for today's students to gain is how to be practicing law in the last half of the twenty-first century and the challenge of legal education, helping them navigate toward that indefinite future (Morgan, 2005).

To become a licensed legal practitioner in the Kingdom of Saudi Arabia, a candidate must nominally obtain a Bachelor of Law degree (LL.B.) from a certified law school or be a holder of a degree from a Sharia college. Also, the candidate must achieve all mandatory requirements and have previous legal experience in the Kingdom for a minimum period of three years after graduation. According to Paragraph (C) of Article (3) of the Saudi Code of Law Practice (2001), certain law degrees may require specific apprenticeships for graduates to acquire a permit of law practice. Accordingly, the requirement of legal experience under the direct supervision of a licensed attorney or at legal departments are no longer considered a viable educational option. The requirement is considered for evidence of a lack of trust from stakeholders and specialists in the effectiveness of law programs that provided by law schools in the State. Additionally, it demonstrates that law programs and the methods of education in the Kingdom are weak and have a deficiency in promoting deep comprehension of law and preparing students to be responsible professionals in a speedily shifting interdependent world. With the development of legal education tools, the legal apprenticeship has become almost extinct and has ceased to exist only in a few countries that do not trust in the possibilities of its legal education.

Fundamentally, legal education in the Kingdom is based on theories presented through lecture and textbook study. Students are expected to take copious notes and memorize theories in preparation for examinations. Many of the senior members of the instructional staff consider the system to be time proven and vigorously pursue a position of retaining it. However, the younger perhaps more internationally educated members of the staff feels that modifications and enhancements to the lecture presentation systems may substantially improve both the quality of legal education and expertise of graduates going into law practice.

It must never be thought that the lecture method has become outdated; no longer viable in education! Precisely the opposite is true, now, more so than ever before, the experience and knowledge of Saudi Arabian legal experts lecturing in law schools can be the wellspring of improving the legal profession. However, it cannot do it without the dedication and cooperation of both legal experts and governmental authorities. The present-day Saudi legal education programs rely heavily on the traditional lecture method, to cast it out as old and worn, is arbitrarily eliminating hundreds of years of knowledge and perhaps ideas for improvement that never came to fruition. Whatever the case, there is no logical replacement for a knowledgeable human instructor lecturing eager students. The problem lies in the absence of instruction and application of critical thinking and problem-solving skills needed to address challenging both domestic and international legal issues.

English is now the global language of business. More and more multinational companies are mandating English as the typical corporate language to facilitate communication and performance across geographically diverse functions and business endeavors (Neeley, 2012). In Saudi Arabia, the ability to speak English became a sign of prestige, an opportunity for better education, and a definite asset in the business and legal arenas. Furthermore, public opinion of English as a mode of instruction was seen as highly competent and considered an essential skill that all nationals should possess (Nash, 2016). Regrettably, law graduates suffer a deficiency in English, because the schools' study plans do not consider it a priority in their curriculum outlines.

Often the deficiencies in the principles and instruction methods are the cause of the failure of many graduates in the practicum failed. Thus, the deficiencies in the preparation of law students by the failure to provide training in practical skills, lawyering skills, legal analysis, reasoning, research, legal investigation, and negotiation, mediation, and communication skills should not be put directly on the shoulders of the student. It is proven that the more unique skills required by law students demand much better training in problem-solving, analysis, legal-writing, cooperative skills, argument, and English language. Each legal education model fails to deliver these skills. It paddles upstream against the natural flow of global legal education. In fact, prospective legal professionals need a more holistic approach instead of merely teaching legal principles and traditions of the profession. Law schools need to innovate in 
the creation of their instructional curriculum and method to convince those interested in the additional value of the investment in their offerings.

Currently, all parties concerned with the success of legal education in the Kingdom, need to expand their opinions and accept the fact that not enough is being done to educate law school students appropriately. Substantial effort must be put forth to improve not just the curriculum and syllabi, but also the teaching skills of the instructional staff that will allow them to instill the legal skills, professional judgments, and ethical values required of Saudi legal practicians (Cassidy, 2014). According to the present Saudi legal education philosophy, the "lecture method" is the superior format for teaching law. It requires very little from the student other than to remain alert, polite, and to take copious notes for independent study. In turn, the lecturer is expected to know his topic and the information in any textbooks used. It is designed to adhere to a standard syllabus of three sections: Introduction, lecture and summary; all delivered without interaction with the students.

Amid these circumstances, any proposal for improving the legal education methods offered might better be addressed by examining options for thoroughly reforming the legal education system. They are, however, not free of challenges, and potentially open to attack from the "old guard" who believe themselves guardians of education and, as such, are not willing to abandon historical approaches. Therefore, an examination of the association between the educational outcomes of students and teaching models of Saudi law education is necessary. It will end with suggestions that the adoption of modern academic performance will achieve higher outcomes for students under multiple flexible models. Each is an attempt at evolving education, especially while addressing the challenges of supplying higher education for a growing number of students. The projected result is meeting the demand for providing the labor market with professionals as well as enhances the quality of education's outcomes.

\section{Sailing Along with the French Model}

The legal studies curriculum in Saudi Arabia closely follows the Egyptian school, which in turn was heavily inspired by the curriculum of the French legal schools. Since the end of the nineteenth century, legal education in France has been viewed as a general preparation for a career in fields other than law. In fact, only a very small proportion of French law graduates enter the legal profession, and those who do are given practical training by way of either an apprenticeship program or further study in a specialized school. It should be mentioned that the French legal system and the legal education system in the countries that follow the French model, aim to educate jurists as opposed to the training of lawyers (Carbonneau, 1980). In a word, the legal education model of those countries symbolizes traditional academia which is centered on the earlier educational system dominant in the teaching substantive legal doctrine, a system that has ultimately been proven to be ineffective.

With the beginning of the establishment of the legal curriculum in Saudi universities and thanks to the Egyptian professors, the French model (lecture method) had been adopted and was accepted as the prevalent and dominant model. The lecture methodology is considered an extension of the method of teaching in public education, which makes it readily adopted by students in law schools. However, this model suffers from some problems, most notably the failure to give sufficient attention to the application of legal rules to solve sample lesson problems. It is also considered to be an ineffective model for the development of student analytical skills. With the neglect of practicum training in the curriculum and no attention given to equipping students with the ability to critically think as lawyers to solve legal issues, the legal education model, in this case, is failing to achieve its objectives.

Since the original French legal education model has rectified this imbalance by introducing weekly sessions of individual practical work, it has become more students friendly. Unfortunately, the Saudi approach, once inspired by the French model, did not keep up with the reformation that occurred to the legal education methods of France. As an obvious result, the upgrading of this method within the Kingdom has become an imperative, especially since the State plans to promote education reform through its "Kingdom Vision" program; an agenda it plans to share with developing countries.

\section{Comparative Perspective on Legal Education: the KSA-French-the U.S.}

Law schools in Saudi Arabia, France, and America have designed significantly different systems for the education of prospective lawyers. While the Saudi and French students have comparatively similar programs; the American schools provide appreciatively dissimilar legal educations. In Saudi Arabia, the number of law school admissions is determined by the Ministry of Education, which allocates a specific number of students to each university. Positioned in each school is an admissions committee that functions to receive applications and sort them based on the candidates' grades and personal desires with emphasis primarily driven by the employment market (Serag, 2002). Additionally, admissions do not require specific testing such as the American Law School Admissions Test (LSAT) 
and a specific Grade Point Average (GPA) (Newton, 2012), both of which are not considered critical factors in acceptance determinations for Saudi law schools

The fundamental nature of legal education schools in both Saudi Arabia and France is that of university-based legal academic programs departmentalized on a similar basis as other countries. The instructional staff are both full- and part-time paid employees reporting to a department head as well as appropriate deans. In many schools, some Law programs are associated with Political Science programs where which may or may not give it more emphasis on governmental legislation (Habermacher, 2018). However, the primary problem is that the curriculums are heavily focused on the science of legal theory rather on developing the necessary skills a new lawyer will need to set up, and more importantly, maintain a growing legal practice.

In the Kingdom, students who wish to become attorneys are required to take four years of theoretical legal teaching training to receive their law degree. On completion, they are required to register for an additional three years in an apprenticeship program consisting of participating, as approved and under the supervision of a licensed attorney, the routine legal casework. It is hoped that each student will be exposed to both law office operations and in-court cases during this period. The emphasis on this program is to expose the student to actual client contact, preparation of appropriate legal documents, preparing arguments and participate in the actual court proceedings on a limited basis. Admittedly, there is a potential for shortcomings and exploitation of the students such as those assigned to do only personal correspondence or providing services unrelated to the legal practice and other personal interests.

The legal education system for French students is different in that before entering universities; they select a specific area of law they wish to study. The objective is to serve both the student and the legal market better. On receipt of their Bachelor's Degrees, they must complete a Master's program before being allowed to enroll in the I'Ecole du Barreau (the School of Bar) which involves an eighteen-month period of professional training before being allowed to take their oath as an attorney (Habermacher, 2018). In America, potential law students must complete a four-year Bachelor's Degree program before they are accepted into law school. Additional to this, all schools require the satisfactory completion of the LSAT exam within no more than one year before their desired first-semester starting date. Acceptance in the three-year Juris Doctorate (J.D.) law programs requires both high range Grade Point Averages (GPA) in undergraduate programs and on the LSAT. The actual final exam for students in the state bar associations licensing exam for the state in which they wish to practice. In reference to this comment, the essential steps lie in the initiative of reforming legal education methodologies adopted in the State which are seen as the banner of theoretical legal education. Calls for reforming legal education methods may receive some acceptance by following the French experience. The table 1 below breaks down the differences and similarities between the legal education in the Saudi Arabia, France, and America. 
Table 1. Comparison of Legal Education System Between the KSA, France and the USA

\begin{tabular}{|c|c|c|c|}
\hline Country & Saudi Arabia & France & The United States \\
\hline $\begin{array}{c}\text { Type of } \\
\text { institutions }\end{array}$ & $\begin{array}{l}\text { Law institutions are } \\
\text { departments of their } \\
\text { universities like any other } \\
\text { academic program }\end{array}$ & $\begin{array}{l}\text { Law institutions are departments } \\
\text { of their universities like any } \\
\text { other academic program }\end{array}$ & $\begin{array}{l}\text { Professional schools in the } \\
\text { university setting; for financial } \\
\text { reasons, they are now part of their } \\
\text { universities but still continue to } \\
\text { enjoy a semi-autonomous } \\
\text { functioning }\end{array}$ \\
\hline $\begin{array}{l}\text { Education } \\
\text { objectives }\end{array}$ & $\begin{array}{l}\text { The legal education focuses } \\
\text { on theoretical knowledge of } \\
\text { law science. Education } \\
\text { seeks to educate legal } \\
\text { experts (jurists) rather than } \\
\text { train future attorneys }\end{array}$ & $\begin{array}{l}\text { The legal education focuses on } \\
\text { theoretical knowledge of law } \\
\text { science. Education seeks to } \\
\text { educate legal experts (jurists) } \\
\text { rather than train future attorneys }\end{array}$ & $\begin{array}{l}\text { The training approach for future } \\
\text { attorneys is more deeply ingrained } \\
\text { in American legal education }\end{array}$ \\
\hline $\begin{array}{c}\text { Law } \\
\text { degrees }\end{array}$ & $\begin{array}{l}\text { Legal education is provided } \\
\text { as an undergraduate } \\
\text { program (Bachelor of Laws, } \\
\text { LLB); LLM (Master of } \\
\text { Laws) and (Ph.D.) doctoral } \\
\text { program in law. }\end{array}$ & $\begin{array}{l}\text { Legal education is provided as } \\
\text { an undergraduate program } \\
\text { (Bachelor of Laws, LLB); LLM } \\
\text { (Master of Laws) and (Ph.D.) } \\
\text { doctoral program in law. }\end{array}$ & $\begin{array}{l}\text { Law is taught as a post-graduate } \\
\text { degree after receiving a B.A.; the } \\
\text { three-year law program that leads } \\
\text { to a Juris Doctor (J.D.) degree. }\end{array}$ \\
\hline $\begin{array}{l}\text { To be a } \\
\text { lawyer }\end{array}$ & $\begin{array}{l}7 \text { years after high school to } \\
\text { be qualified for practice law. } \\
4 \text { years studying and } 3 \text { years } \\
\text { of apprenticeships. }\end{array}$ & $\begin{array}{l}7 \text { years studying is the time } \\
\text { between the end of high school } \\
\text { to be qualified to practice law. }\end{array}$ & $\begin{array}{c}\text { Students take } 7 \text { years studying after } \\
\text { high school to be qualified to } \\
\text { practice law. }\end{array}$ \\
\hline $\begin{array}{l}\text { Methods } \\
\text { of } \\
\text { teaching }\end{array}$ & $\begin{array}{l}\text { The pedagogy is based on } \\
\text { operating lectures. Students } \\
\text { do not fear to be "on call." } \\
\text { Professors focus on a } \\
\text { theoretical approach to law. }\end{array}$ & $\begin{array}{l}\text { The pedagogy is based on } \\
\text { operating lectures. Students do } \\
\text { not fear to be "on call." } \\
\text { Professors focus on a theoretical } \\
\text { approach to law. }\end{array}$ & $\begin{array}{l}\text { Professors use interactive methods; } \\
\text { call on students randomly for } \\
\text { refined answers. Teaching methods } \\
\text { rely on the case/Socratic, clinical } \\
\text { education, } \\
\text { Problem-Based-Learning. }\end{array}$ \\
\hline
\end{tabular}

\section{Conclusions}

This research explores the legal education model of the Kingdom of Saudi Arabia and also compares the basic components of the education model with France and the US. Historically, the Arab legal system is stemming from the Roman Law. The Arab teaching model is derived from the French model and French codified system of law spread in the Middle East. This system becomes popular in the Arab world due to the North African professors in the Arab especially the Egyptians who graduated from the French law schools. In the whole, French schools divide the whole law into two branched: public and private. In Saudi Arabia, the legal education is initiated by IPA located in Riyadh during the 1970s. IPA offered a-two years diploma after to the Sha'ria graduates and generally follows the lecture-based method of teaching as per French model of teaching. After the IPA efforts, the legal eduaction becomes popular in the university education once the King Saud University started the legal education during the 1980s based on the Egyptian models. Generally, law graduates require at least a 4-years law degree (LL.B.) and a 3-years apprenticeship to practice in the courts. With an effort of IPA and university legal education, law graduates are meeting the market demand for legal professionals for parctice. This research also differentiates the legal education system of France, Saudi Arabia and US and finds that Saudi Arabian system is more similar to French system but different from the US system.

\section{References}

Al-Jarbou, A. M. (2007). The Role of Traditionalists and Modernists on the Development of the Saudi Legal System. Arab Law Quarterly, 21(3), 191-229. https://doi.org/10.1163/026805507X226827

Carbonneau, T.E. (1980). The French Legal Studies Curriculum: Its History and Relevance as a Model for Reform. 25 McGill L.J. 445. http://elibrary.law.psu.edu/fac_works 
Cassidy, R.M. (2014). Reforming the Law School Curriculum from the Top Down. Journal of Legal Education, 64, Boston College Law School Legal Studies Research Paper No. 335. https://ssrn.com/abstract=2496561

Flood, J. A. (2011). Legal education in the global context: challenges from globalization, technology and changes in government regulation. University of Westminster School of Law Research Paper No. 11-16. http://dx.doi.org/10.2139/ssrn.1906687

Habermacher, A. (2018). A French-American Perspective on Legal Education: Institutions, Experience, And Debate. Columbia Law School's Journal of Law and Social Problems. http://clscommonlaw.com

Hanson, M. (1987). The Influence of French Law on the Legal Development of Saudi Arabia. Arab Law Quarterly, 2(3), 272-291. https://doi.org/10.1163/157302587X00318

Kaur, G. (2011). Study and Analysis of Lecture Model of Teaching. International Journal of Educational Planning \& Administration, l(1), 9-13. http://www.ripublication.com/ijepa.htm

Morgan, T.D. (2005). Educating Lawyers for the Future Legal Profession. Oklahoma City University Law Reviews Symposium on the future of the Legal Profession. https://ssrn.com/abstract=881846

Nash, J.A. (2016). New curriculum design and teaching methods to enhance course performance and increase motivation of Saudi Arabian college students. Learning and Teaching in Higher Education: Gulf Perspectives, 13(2), 1-17. https://doi.org/10.18538/lthe.v13.n2.235

Neeley, T. (2012). Global Business Speaks English. Harvard Business Review-Cross Cultural Management. Retrieved from https://hbr.org/2012/05/global-business-speaks-english

Newton, B.E. (2012). The Ninety-Five Theses: Systemic Reforms of American Legal Education and Licensure. South Carolina Law Review, 64. https://ssrn.com/abstract=1994189

Romantz, D.S. (2003). The Truth About Cats and Dogs: Legal Writing Courses and the Law School Curriculum. Kansas Law Reviews, 52, University of Memphis Legal Studies Research Paper No. 36. https://ssrn.com/abstract=1633953

Serag, M. (2002). Legal Education in Egypt. South Texas Law Review, 615. https://heinonline.org/HOL/LandingPage?handle=hein.journals/stexlr43\&div=45\&id=\&page=

Sultany, N. (2018). Law and revolution: Legitimacy and Constitutionalism after the Arab spring. Oxford University Press, New York, 15-65. 